
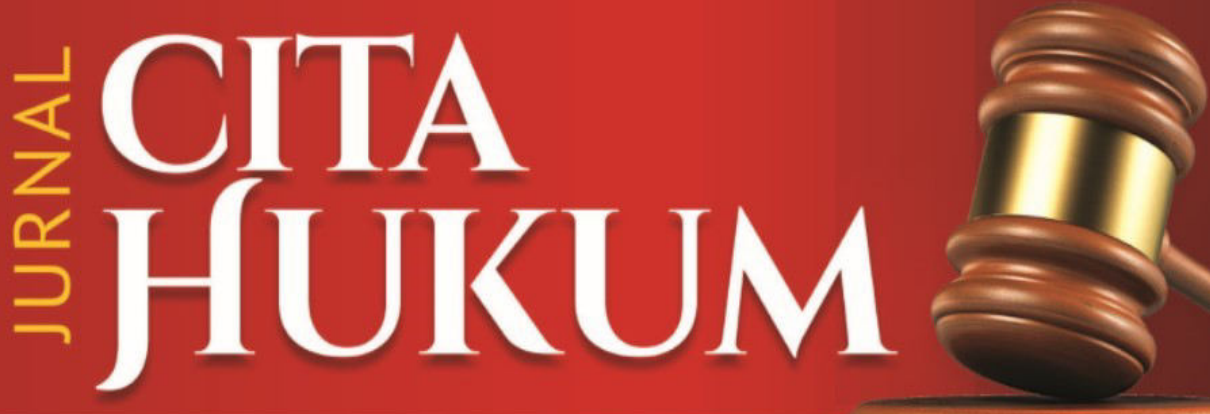

Indonesian Law Journal

- Understanding Violent Religious Behavior in Indonesia: From the Concept to the Prevention Dana Riksa Buana, Oleg Valeryevich Lukyanov (Tomsk, Russian Federation)

- The Direction of Police Community Policy In The Prevention of Traffic Accidents In Polda Metro Jaya Rudi Antariksawan, Muhammad Mustofa (Jakarta, Indonesia)

- Investigating the Injuries of Murder in Prohibition in Iranian Laws Jahangir Mirmohamadi \& Hamidreza Adabi. (Islamic Republic of Iran)

- The Management of Conflict Resolution On Labor Wages Sarwani, RR. Dewi Anggraeni \& Annissa Rezki. (Pamulang, Indonesia)

- The Application of the Strict Liability Principle in The Indemnity Laws for Livelihoods in Indonesia; Analysis of The Supreme Court's Decision Number 1794K/PDT/G/2004 Ahmad Tholabi Kharlie. (Jakarta, Indonesia)

- Settlement Through Mediation Between the Normative and Practice in Religious Judiciary Agencies Karmawan \& Masykuri Abdillah. (Banten, Indonesia)

- The Impact of Regulation Policy In Indonesia Against Women's Family Head Ana Kuswanti, Amiruddin Saleh, Aida Vitayala S Hubeis, Herien Puspitawati \& Munadhil Abdul Muqsith. (Bogor, Indonesia)

- Conceptualization and Problems in the Implementation of Fostered Children's Health Services to Support The Progressiveness of the Child Criminal Justice System in Tangerang Children's Penitentiary Alfitra \& Ali Mansur. (Jakarta, Indonesia)

- Implication of Law Number 23 of 2011 On Zakat Institution Governance Based On Sharia Quality Management Principles; A Case Study in Baznas of Jambi Province Muhammad Zaki, Amiur Nuruddin, Saparuddin Siregar. (Jambi \& Medan, Indonesia)

- Indonesian State Owned Enterprises (BUMN or SOEs) and the Urgency of Implementation of Principle of 'Business Judgment Rule' Teuku Syahrul Ansari, Herdi Sahrasad \& Irfan Iryadi. (Semarang \& Jakarta, Indonesia)

- Understanding the Rights of Wife in The Law Number 1 of 1974 About Marriage Among the Terrorist Wives in Central Java Rosdiana \& Hotnidah Nasution. (Jakarta, Indonesia)

- Государственное регулирование закупок учебного оборудования и инфраструктуры в школах (Government Regulation in the Procurement of Teaching Facilities and Infrastructures in Schools) Zaharah \& Galia Ildusovna Kirilova. (Kazan, Russian Federation)

\title{
Volume 8 Number 1 (2020)
}




\section{Jurnal}

\section{CITA HUKUM}

\section{VOLUME 8 NUMBER 1 (2020)}

JURNAL CITA HUKUM is Indonesian Law Journal published by Faculty of Sharia and Law, State Islamic University Syarif Hidayatullah Jakarta in Associate with Center for Study of Indonesian Constitution and Legislation (POSKO-LEGNAS) UIN Jakarta.

This journal specializes in Legal Studies and try to present various results of the latest and high-quality scientific research.

As an International Journal, all articles must be written in English or Russian, because they will be read online by millions of readers, both speakers of English and Russian.

JURNAL CITA HUKUM has been indexed at Web of Science (WOS) Web of Science (WOS) or Emerging Source Citation Index (ESCI) Clarivate Analytics, DOAJ, EBSCO, DIMENSION, Microsoft Academic Search, and SINTA 2 and become a CrossRef Member since year 2015. Therefore, all articles published by JURNAL CITA HUKUM will have unique DOI number.

\section{INTERNATIONAL EDITORIAL BOARD}

Prof. Carolyn Sappideen, Scopus ID: 6506771331 School of Law Western Sydney University, Australia

Prof. Alexander Fedorovich Malyy, Scopus Id: 57194874834, Department of Constitutional Law, Kazan Federal University, Russian Federation

Prof. Razeen Sappideen, Scopus ID: 14041008300 School of Law Western Sydney University, Australia

Prof. Stefan Koos, Bundeswehr University Munich

Prof. Muhammad Munir, Scopus ID: 54414595100, Department of Law, International Islamic University Islamabad, Pakistan

Prof. Euis Nurlaelawati, Scopus ID: 56247081700, Faculty of Sharia and Law, State Islamic University (UIN) Sunan Kalijaga Yogyakarta

Prof Abdul Gani Abdullah, Universitas Islam Negeri Syarif Hidayatullah Jakarta

Prof. Salman Maggalatung, Center for the Study of Constitution and National Legislation (POSKOLEGNAS), Indonesia

Prof. Asep Saepudin Jahar, Scopus ID: 57156653300 , Department of Economic Law Universitas Islam Negeri Syarif Hidayatullah Jakarta

Assoc. Prof. Ahmad Tholabi Kharlie, Thomson Reuters Id: R-5028-2017, Department of Family Law, Faculty of Sharia and Law, Universitas Islam Negeri Syarif Hidayatullah Jakarta

\section{EDITOR IN CHIEF}

Nur Rohim Yunus, Scopus ID: 57216167775, Thomson Reuters Researcher ID: F-3477-2017, ORCID ID: 0000-0003-27821266, SSRN ID: 2645355, SINTA ID: 5975443, Department of Constitutional Law, UIN Syarif Hidayatullah Jakarta, Indonesia

\section{MANAGING EDITOR}

Muhammad Ishar Helmi, Scopus ID: 57214681602, Department of Criminal Law Faculty of Sharia and Law Universitas Islam Negeri Syarif Hidayatullah Jakarta, Indonesia.

\section{EDITORS}

Indra Rahmatullah, Scopus ID: 57215568835, Department of Economic Law, Faculty of Sharia and Law Universitas Islam Negeri Syarif Hidayatullah Jakarta, Indonesia.

Fitria Fitria, ORCID ID: 0000-0001-9733-1233, Department of International Law, York Law School, University of York, UK, United Kingdom.

Mara Sutan Rambe, ORCID ID: 0000-0001-5404-6635, SINTA ID: 6200494, Department Criminal Law, Faculty of Law, UIN Syarif Hidayatullah Jakarta, Indonesia.

Erwin Hikmatiar, Thomson Reuters Researcher ID: F-3235-2017, ORCID ID: 0000-0003-4103-818X, SINTA ID: 6200141, Center for The Study of Constitution and National Legislation (POSKOLEGNAS), UIN Jakarta.

Arip Purkon, ORCID ID: 0000-0002-6195-9384, Department of Law, University of Malaya, Malaysia.

\section{LANGUAGE EDITOR (ENGLISH AND RUSSIA)}

Raisa Shahrestani, Belgorodsky State University, Russia.

Firsty Izzata Bella, Airlangga University, Surabaya, Indonesia.

\section{ASSISTANT TO THE EDITORS}

Imas Novita Juaningsih, State Islamic University (UIN) Syarif Hidayatullah Jakarta, Indonesia.

Rezky Panji Perdana Martua Hasibuan, State Islamic University (UIN) Syarif Hidayatullah Jakarta, Indonesia.

Azizah Ratu Buana, State Islamic University (UIN) Syarif Hidayatullah Jakarta, Indonesia.

\section{Redaktur Office}

Faculty of Sharia and Law UIN Syarif Hidayatullah Jakarta

Street Ir. H. Juanda 95 Ciputat Jakarta 15412

Phone. (62-21) 74711537, Faks. (62-21) 7491821

Website: www.fsh-uinjkt.net, E-mail: jurnal.citahukum@uinjkt.ac.id.

Link: http://journal.uinjkt.ac.id/index.php/citahukum 


\section{TABLE OF CONTENTS}

Understanding Violent Religious Behavior in Indonesia: From the Concept to the Prevention

Dana Riksa Buana, Oleg Valeryevich Lukyanov

The Direction of Police Community Policy In The Prevention of Traffic Accidents In Polda Metro Jaya

Rudi Antariksawan, Muhammad Mustofa..

Investigating the Injuries of Murder in Prohibition in Iranian Laws

Jahangir Mirmohamadi, Hamidreza Adabi ..

The Management of Conflict Resolution On Labor Wages

Sarwani, RR. Dewi Anggraeni, Annissa Rezki

The Application of the Strict Liability Principle in The Indemnity Laws for Livelihoods in Indonesia; Analysis of The Supreme Court's Decision Number 1794K/PDT/G/2004

Ahmad Tholabi Kharlie.

Settlement Through Mediation Between the Normative and Practice in Religious Judiciary Agencies

Karmawan, Masykuri Abdillah

The Impact of Regulation Policy In Indonesia Against Women's Family Head

Ana Kuswanti, Amiruddin Saleh, Aida Vitayala S Hubeis, Herien Puspitawati, Munadhil Abdul Muqsith

Conceptualization and Problems in the Implementation of Fostered Children's Health Services to Support The Progressiveness of the Child Criminal Justice System in Tangerang Children's Penitentiary

Alfitra, Ali Mansur 123-144

Implication of Law Number 23 of 2011 On Zakat Institution Governance Based On Sharia Quality Management Principles; A Case Study in Baznas of Jambi Province

Muhammad Zaki, Amiur Nuruddin, Saparuddin Siregar

Indonesian State Owned Enterprises (BUMN or SOEs) and the Urgency of Implementation of Principle of 'Business Judgment Rule'

Teuku Syahrul Ansari, Herdi Sahrasad, Irfan Iryadi

Understanding the Rights of Wife in The Law Number 1 of 1974 About Marriage Among the Terrorist Wives in Central Java

Rosdiana, Hotnidah Nasution

Государственное регулирование закупок учебного оборудования и инфраструктуры в школах (Government Regulation in the Procurement of Teaching Facilities and Infrastructures in Schools)

Zaharah, Galia Ildusovna Kirilova 


\title{
The Direction of Police Community Policy In The Prevention of Traffic Accidents In Polda Metro Jaya*
}

\author{
Rudi Antariksawan, ${ }^{1}$ Muhammad Mustofa ${ }^{2}$ \\ Criminology, Social and Political Science, Universitas Indonesia, Depok, \\ Indonesia \\ $\underline{10.15408 / j \mathrm{jch} . v 8 \mathrm{i} 1.13762}$
}

\begin{abstract}
There are three core functions of the police, law enforcement, order maintenance, and services to the community or public services. One part of the law enforcement function is preventing and overcoming traffic violations. Traffic accidents have a large and detrimental impact, and this is one of many indicators of the success of the police. Traffic accidents are often caused by drivers who do not obey the rules, so they endanger themselves or others. In addition to violations by drivers, other things that become the factor occurrence of traffic accidents are road quality, human error, and vehicle worthiness. The purpose of this study was to determine the direction of community policing policies in dealing with traffic violations, and efforts to develop community policing models by paying attention to public participation and the role of the police in preventing traffic violations. The results obtained show that significant factors that caused the occurrence of high accidents per population were factors related to drivers or human factors, where the dominant violation was a violation of the speed limit. By knowing that the main factor of accidents is the human element, the policies taken to overcome this are policies related to humans, namely community policing.
\end{abstract}

Keywords: Police Community, Traffic Violations, Traffic Accidents

* Received: December 23, 2019, revised: January 11, 2020, accepted: February 25, 2020, Published: March 19, 2020.

${ }^{1}$ Rudi Antariksawan is a Ph.D Candidate at Criminology, Social and Political Science, Indonesia University, Depok.

2 Muhammad Mustofa is a Professor of Criminal Law at Faculty of Law, Indonesia University, Depok, Indonesia.

*Corresponding Author: rudiantariksa@yahoo.com. 


\title{
Arah Kebijakan Komunitas Polisi Dalam Pencegahan Kecelakaan Lalu Lintas Di Polda Metro Jaya
}

\begin{abstract}
Abstrak
Ada tiga fungsi inti polisi; penegakan hukum, pemeliharaan pesanan, dan layanan kepada komunitas atau layanan publik. Salah satu bagian dari fungsi penegakan hukum adalah mencegah dan mengatasi pelanggaran lalu lintas. Kecelakaan lalu lintas memiliki dampak yang besar dan merugikan, dan ini adalah salah satu dari banyak indikator keberhasilan polisi. Kecelakaan lalu lintas sering disebabkan oleh pengemudi yang tidak mematuhi aturan, sehingga membahayakan diri mereka sendiri atau orang lain. Selain pelanggaran oleh pengemudi, hal lain yang menjadi faktor terjadinya kecelakaan lalu lintas adalah kualitas jalan, kesalahan manusia, dan kelayakan kendaraan. Tujuan dari penelitian ini adalah untuk menentukan arah kebijakan pemolisian masyarakat dalam menangani pelanggaran lalu lintas, dan upaya untuk mengembangkan model pemolisian masyarakat dengan memperhatikan partisipasi publik dan peran polisi dalam mencegah pelanggaran lalu lintas. Hasil yang diperoleh menunjukkan bahwa faktor signifikan yang menyebabkan terjadinya kecelakaan tinggi per populasi adalah faktor yang berhubungan dengan faktor pendorong atau manusia, dimana pelanggaran dominan adalah pelanggaran batas kecepatan. Dengan mengetahui bahwa faktor utama kecelakaan adalah unsur manusia, kebijakan yang diambil untuk mengatasinya adalah kebijakan yang terkait dengan manusia, yaitu pemolisian masyarakat.
\end{abstract}

Kata kunci: Komunitas Polisi, Pelanggaran Lalu Lintas, Kecelakaan Lalu Lintas

\section{Направление политики полицейского сообщества по предотвращению дорожно-транспортных происшествий в Полда Метро Джая (Джакарта Рая - Столичной Региональной Полиции)}

\begin{abstract}
Аннотация
Существуют три основные фуннции полиции: правоохранительные органы, сохранение порядка и обслуживание населения или общественных служб. Одна из функций правоохранительных органов - это предотвращение и преодоление нарушений правил дорожного движения. Дорожные происшествия оказывают большое и пагубное влияние и являются одним из многих показателей успеха работы полиции. Дорожные происшествия часто вызваны водителями, которые не подчиняются правилам, поэтому они подвергают опасности себя или других. Помимо нарушений со стороны водителей, другим факторами, которые становятся причинами дорожных происшествий, являются качество дороги, человеческая ошибка и качество автомобиля. Цель этого исследования состояла в том, чтобы определить направление политики Совместной Охраны Порядка (Community Policing) в борьбе с нарушениями правил дорожного движения и усилия по разработке моделей Совместной Охраны Порядка, уделяя внимание участию общественности и роли полиции в предотвращении нарушений правил дорожного движения. Полученные результаты показывают, что значительными факторами, которые стали причиной большого количества аварий на одного человека, были факторы, связанные с водителями или человеческими факторами, где доминирующим нарушением было нарушение ограничения скорости. Так как основным фактором является человеческий, меры, предпринимаемые для его преодоления, являются мерами, связанными с людьми, а именно с Совместной Охраной Порядка.

Ключевые слова: Полицейское сообщество, Нарушение правил дорожного движения, Дорожные происшествия
\end{abstract}




\section{Introduction}

In-Law No.2 the Year 2002 has been described in section 2 that the function of the police is one of the functions of the state government in the field of maintenance of security and public order, law enforcement, protection, shelter, and services to the community. In line with this, according to Larry J. Siegel, there is 3 core function of the police, i.e. law enforcement, order maintenance, and service function (Siegel, 2000). In order maintenance or the field of maintenance of security and public order, police duties also include order and security on the highway. Setting the behaviour of people driving is also a concern for the police institution to create safe traffic conditions and order.

Based on the Regulation of the Head of the State Police of the Republic of Indonesia Number 21 the Year 2010 it is mentioned that in the structure of the Indonesian Police, there are Traffic Corps (Korlantas), which is implementing the basic tasks of the Police the fields of security, safety, order, and smoothness of traffic on the level of Police Headquarters that are under the Chief of police. Meanwhile, according to Regulations of the Head of the State Police of the Republic of Indonesia Number 22 the Year 2010 in Organization and Working procedures At the Level of Regional Police stated that the Traffic Directorate is implementing elements of the basic tasks at the level of Police. So at the level of Police, the executors of the principal task are the polices in the fields of safety, order, and smoothness of traffic is the Traffic Directorate (Ditlantas).

In Indonesia, the number of motor vehicles is increasing every year and the negligence of humans is a major factor that increased the occurrence of traffic accidents. The Data of the State Police of the Republic of Indonesia said that in 2012 occurred 109.038 cases of an accident with dead casualties as much as 27.441 people. In addition to victims of traffic accidents is dominated by the young and productive age, most of the cases the accident occurred in the poor society as users of the motorcycle, and public transportation.

Report on the Global Status Report and Road Safety, five things become the key behavioral risk factors, namely some of the risky behaviors that correlate with the occurrence of the accident, on the report Indonesia has implemented four of five from the behavioral risk factor, that is point number 1 to number 4 . These five factors that referred are :

1. Rules related to vehicle speed,

2. Rules related to the conditions of the hangover, 
3. Rules of the use of helmets for two-wheeler riders,

4. Rules of use of seat belts for passengers.

5. Rules for the car with the seat designed for children,

Still in the same report, are given an overview of historical data regarding the number of death of accident victims per 100,000 population since the year 2010 to 2016 .

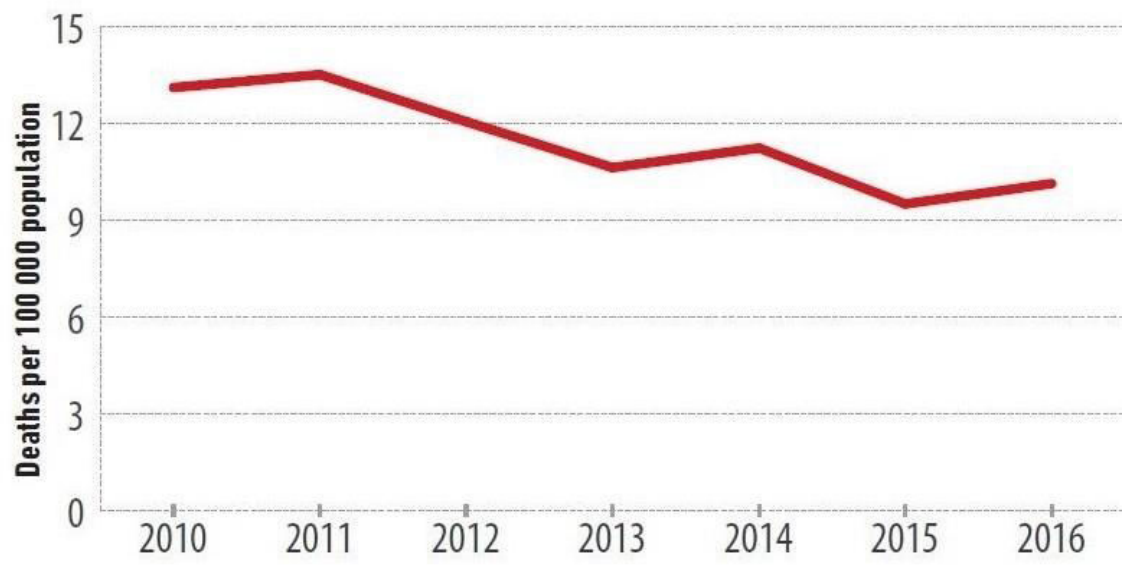

\section{Graph 1. Victim's death in a traffic accident}

Source: Global Status Report and Road Safety (2018)

The figure above shows a tendency of a declining number of victim's fatalities in accidents per hundred thousand population, it can be seen in the picture above if there is a decrease in the ratio, however, should be noted that the number of residents each year is always increasing, so that the decrease in ratio does not mean the decrease in the number of accidents that actually.

Therefore, traffic accidents become one of the indicators in determining the success of the performance of the Directorate of Traffic Polda Metro Jaya. It is as expressed by Henry Lowenstein (1984) who states that one measure of success of the police in traffic management is to improve public safety (Lowenstein, 1984).

Traffic accidents that occur are often caused because many riders do not adhere to the rules of driving so that they often perform actions that endanger 
their lives or others. This is in line with that been said by Badh (2014) who says that the terminology of an accident (accident) is not appropriately used to describe the careless behavior of road users (Badh, 2014).

Farouk Muhammad (1998) also added that traffic violations in Indonesia are a major problem, especially in large cities, often resulting in traffic congestion both of which seem to result in a traffic accident and also have an impact on the safety of other road users. It is known that most of the traffic accidents in Indonesia were due to the failure of drivers to comply with basic traffic rules (Muhammad, 1998).

In addition to violations committed by road users, other things can be the cause of the occurrence of a traffic accident is the quality of the facilities and infrastructure of the road, and also the human error factor/ behavior of the driver and the compliance of the vehicle.

With regards to how officers should preparing and doing law enforcement in the context of traffic, then according to the implementation guidelines (Juklak) Police as described by Muhammad (1998) gives the following standards:

1. An officer is required to immediately and completely stop the car when he finds or suspects that a violation has occurred.

2. He needed to approach the driver with a smile, greetings, and respect (known as the procedure of 3S) and explain to participants the type of violations that been has done, and to take action regarding this violation.

3. An officer can issue a speeding ticket if the violation is serious, but can choose to only rebuke the driver if they committed a minor offense (Muhammad, 1998).

During this time efforts have been that aim to change the risky behavior of the driver of the 2-wheeled, 4 wheeled, or more. This effort is also done by involving the community so it is expected the society will have the awareness to obey the rules of traffic. Acts of intervention that have been done by Ditlantas Polda Metro Jaya during this time are still focused on the efforts of law enforcement. Although it turns out that there has been some actions and activities carried out by Ditlantas Polda Metro Jaya with society involvement such as the socialization of the regulations and ordinances of the drive, but it turns out that these activities do not make changes at the level of a traffic accident that occurred. 
Considering these things, it can be concluded that the policing that has been done during this time is not yet achieve the target. However, it is still necessary to study whether the manifestation of the concept has been right and solving the true problems or not.

In order the implementation of community policing is to be effective and efficient, actions undertaken and stages that are taken must be based on knowledge of the factors associated with the occurrence of the traffic accident. The factors that can be the cause are including human error, compliance, and facilities, and road infrastructure.

The selection of jurisdiction of Polda Metro Jaya as the focus of research based on the fact that Jakarta is a barometer in the implementation and enforcement of legal traffic in Indonesia. If the implementation in Jakarta is going well, it is expected that the same can be implemented also in other jurisdictions.

From the explanation above it can be concluded that among the causes of traffic violations is not actualized the perception of which is owned by the offenders, they are not sure that the violations will be punished so that offenders have only a low risk to be punished.

The purpose of this research is to determine the direction of the policy of community policing in the prevention of traffic violations that can cause the rate of traffic accidents causing deaths and injuries increased in 2016-2018, and find the way to develop a model of community policing with attention to community participation and the role of the police in the prevention of violations of traffic so that it can reduce the number of traffic accidents in the jurisdiction of Polda Metro Jaya.

\section{Research Method}

Mannheim (1965) states that the research of criminology has entered the stage of scientific (Mannheim, 1965, p. 85). Based on the research he has been done against the methods of research used in the study of criminology, the methods used are the combination of the main methods, namely: Statistical, Tipological, Individual Case Study, and secondary method, namely: Sociological, Experimental, Predictive, and Operational (Mannheim, 1965, p. 85).

There is a view that doubts the validity and reliability of secondary data, especially data of the police as material analysis. This is disputed by some 
argument which states that the statistical data obtained from the police can be considered to meet the criteria of Validity and Reliability so that it can be used in the study.

One assumption states that the data is not statistically valid and cannot be used in the research is the existence of the Dark Number, this statement can be refuted by assuming that the data obtained from the police is a sample data from the population data that is unknown. While the arguments in favor to declare secondary data police data are reliable is the reality that data is always collected in the same way for many years, this indicates that the method that has been used has a good consistency and can be trusted.

To find out why traffic violations that occur in the jurisdiction of Polda Metro Jaya tend to be higher compared to police the other especially in the area of jurisdiction of police in the Java Island was done by comparing the data of traffic accidents in the region of Polda Metro Jaya Polda with others on the island of Java. The selection of jurisdictions Police in Java Island as the comparison is because Java Island has the largest centralized road network compared to other regions outside of Java Island. So the comparison between region police is appropriate and proportional, then the data traffic will be controlled based on the number of human resources of the traffic police, population, number of vehicles, length of roads, level of public education that is obtained from the National and the Central Bureau of Statistics.

The analysis method that will be used in this research is a combination of quantitative and qualitative methods. The result was obtained from the stages of the quantitative will be taken to the next stages, namely the stages of qualitative analysis. This research was conducted from September 2018 to finish with the place of research in the jurisdiction of Ditlantas Regional Police Metro Jaya.

\section{Research Results and Analysis}

Based on the report issued by POLRI in directing Traffic In Polantas in 2013, 103.784 accidents occurred in 2013. The factors that cause the biggest factor is the Driver Factor, that is equal to $88 \%$ or as much as 91.371 accidents. The second biggest factor is the Road Factors, 7.8 percent, or as much as 8.044 accidents. The third factor is the Vehicle Factors by 3.2 percent or as much as 3.299 , and the fourth is the Natural Factors, $1.0 \%$, or as much as 1.070 events. 
Of some of the things included in the category of Driver Factors, the largest cause of accidents is the Attitude of Disobedient $(45,7 \%)$, Neglectfulness $(32,2 \%)$, Violate the Speed of (14,5\%), Tired / Sleepy (5.7\%) and the Influence of Drugs and Alcohol (1.3 percent).

The standards compiled by the WHO and used as the parameters of the standard the risk of traffic accidents are the rules relating to five of the following, namely Vehicle Speed, Driving in a Drunken Condition, the Use of Helmets on Two-Wheeled Vehicles, Safety Belts for Passengers and Seat Designed for Children.

\section{a. Aspects of Social Control Through Community Policing In the Prevention of Violation of Traffic In Polda Metro Jaya}

Polda Metro Jaya in carrying out the enforcement of traffic laws implements the strategy of community policing by conducting community-based activities. These activities designed by the Directorate of Dikmas Ditlantas Polda Metro Jaya. The implementation of these activities is a form of preventive action of Ditlantas Polda Metro Jaya to prevent traffic violations committed by road users in the jurisdiction of Polda Metro Jaya.

Explanation of Palmiotto and Brown (2008) regarding the services that must be provided to the public also has a relationship with the explanation Dirlantas Polda Metron Jaya how they did a service to the public to keep the order on the streets of the capital. Palmiotto \& Brown (2008) explain how the police must facilitate the movement of people and vehicles and help those who are not able to keep themselves (Palmiotto \& Brown, 2008). Implementation of the strategy of Community Policing programs through the Road Safety Partnership Action aims to maintain the security, safety, order, and smoothness of traffic on the streets of the Capital City.

Duties and functions of the police described by the Bhakti et al (2009) and also the International Crisis Group (2012) that police officers have a responsibility to serve, protect and also protect the public. Under what was described by the OSCE (2008) about how the role of the police, namely the police officers in carrying out their duties are under the pressure of the task, namely as crime control and banish the threats that are present in the community. However, the police must be able to operate following the legislation governing the task and their role. And basically, the police is the same as ordinary people but has an exception in the form they are given specific assignments as a public servant in a democratic society (OSCE, 2008). 
Explanation of Hirschi how crime as an easy way to obtain a personal benefit, but harm and cause harm to other people also following what is described by Black (1984). He explained that to understand social control into two perspectives. First is to understand social control as a process of impact of deviant behavior and investigates why deviant behavior can occur. Then, the second is to understand social control as a reaction to deviant behavior and investigates the impact of such a reaction to the other social phenomenons (Black, 1984).

Implementation of the strategy of community policing is one form of social service provided by the POLRI to society. In line with what has been described by Vito, Walsh, and Kunselman about the importance of the strategy of community policing. They state that the strategy of community policing is a form of partnership that includes the police and also the society they serve as it is essentially the duty of the police (Vito, Walsh, \& Kunselman, 2005).

Social services provided by Polda Metro Jaya in the form of community policing should also pay attention to how the characteristics of the people. In line with what is being described by Cooper (2011) for society, geographically, it is a place or area that small and binding where many people in it know each other and know each other between each other. In there, people have a stable relationship, the relationship is based on the social activities whether it be formal or informal, then the people in that place are united into one unity above sense voluntary, and the existence of an intimate relationship in the form of friendship between each other (Cooper, 2011).

Explanation of Cooper about how society becomes the basis for Polda Metro Jaya in implementing the strategy of community policing to the community, particularly in implementing Dikmas program. The application is in line with the journal article titled Decision Making In Traffic Stop Encounters: A Multivariate Analysis Of Police Behavior on authored by Schaffer et al (2006). He explains that the officer of Central City police conducting traffic law enforcement by racial profiling. Profiling is done by using demographic data of the people living in the city of Central City (Schafer, Carter, Katz-Bannister, \& Wells, 2006).

Explanation of journal articles written by Schaffer can explain aspects of the theory of social control in the implementation of community policing conducted by Polda Metro Jaya for traffic law enforcement. Hirschi (1969) describes conformity as the delimiter. Because the perpetrator of the crime or deviation is seen as an act that is beyond the limits of the restrictions that have been set in society. 
The explanation of Cohen about the social control that shaped the service as well as the prevention of crime following the journal article titled Citizen Willingness to Participate in Police-Community Partnerships: Exploring the Influence of Race and Neighborhood Context that have written by Michael M. Wehrman and Joseph De Angellis. Wehrman and Angelis (2014) explain that in implementing the programs of community policing is an effort to (Wehrman \& Angelis, 2014): a

- Increase the confidence of the minority population to the police;

- Increase a sense of awareness and initiative to participate in the activities preventing crime in the neighborhood they live in.

Explanation of Wehrman and Angelis is one form of limitation that is described by Hirschi in the theory of social control. Because Polda Metro Jaya in carrying out the implementation of community policing with a form of social service as a form of crime prevention then it should be the services provided by Polda Metro Jaya to the citizens of the community in the streets of the capital that can be felt.

\section{b. Social Aspects of Exchange in The Implementation Of Community Policing Strategy In The Prevention Of Traffic Violations By Polda Metro Jaya}

In the enforcement of traffic laws, of course, there is an interaction that occurs between the police and society. As we already know in general that the POLRI has applied to how the strategy of community policing can be effective and also efficient in its implementation. Social interaction between the POLRI with the community is evident from the reaction and the response that appears when the building of interpersonal or intergroup so it was created a bond among them. Social interaction can not be separated also from the social structures that support them (Dermawan, 2011:126).

It can also be seen police are on a social structure that has the authority of the activities in which society lives. In this case, community policing can be realized with the existence of a partnership where the partnership is the result of a social interaction that has been built by the society with the presence of social exchange in the form of trust between the police and the society.

Community policing held by members of the police in the line with duty as well as its function in the enforcement of traffic law is to attempt the appliance of "Kamseltibcarlantas" which has been discussed in the previous 
chapter. As described by Dirkamsel that the application of the community policing is also has a base nature of community empowerment with the knowledge that can be demonstrated to the public that the importance of traffic safety. This was reinforced by the absence of a statement from itself about how important that thing with an education that has characteristics of community empowerment.

In line with that been said by O'Neill and Daniel (2014) re-policing renewed with the series of practices that are incorporated with the solving of a community problem that boils down to how to control the violation of obedience in the community by adding elements of the partnership itself. And of course, a problem-solving community-based in the long-term period (O'Neill \& Daniel, 2014).

The partnership that was formed based on the exchange between police and the society with the long term goal, have one goal that is to provide community services that are primed by the police to the community socially. To prevent violations-traffic violations that could harm road users and prioritizing problem-solving involving society.

The same thing is also described by Price (2015) regarding the partnership. The partnership is valuable in policing. To conduct collaborative partnership is open to the public as well as the elements that are in it will be easier to maintain the security of the public. And to conduct collaborative partnership it will be easier for the police to conduct decision-making when on duty as well as expanding insight and perspective regarding the duties and functions (Price, 2015).

Wang (Wang, 2015) says that the form of the action of the social services of the police includes the resolution of disputes, provision of information, the discovery of the goods lost and found, and humanitarian aid to the needy as well as assistance in case of emergency (Wang, 2015).

Implementation of the strategy of community policing under the explanation of the model of social exchange theory described by Blau (1964) on his book Dermawan (2011) titled Community Policing, where the relationship between individuals or groups when doing exchange that reflects its value and also with the same benefits then will continue to run. And also mutual relations resulting from the exchange by done both parties will continue to take place.

An explanation of community education program traffic is supported by the journal article titled School-Police Partnership Effectiveness in Urban Schools: An Analysis of New York City's Impact Schools Initiative that written by Kevin P. 
Brady, Sharon Balmer, and Deinya Phenix. This article describes how the city of New York in 2004 created a program called Impact Schools. This program involves a partnership between the school and the police department of the city of New York with three objectives, these are (Brady, Balmer, \& Phenix, 2007):

- Improve enforcement of laws against crime and violation of public order and safety of low-level performed by school students in New York;

- Enforcing the rules of discipline of the city of New York for public schools strictly;

- Correcting conditions - the initial conditions of the schools in the city of New York that has the potential for the occurrence of disruption of public order and safety.

Dikmas Lantas Program is intended to all people who have access to traffic especially to children under the age of which are often being the perpetrators of traffic violations. Dikmas Lantas Program if it is associated with the role of social services from the police, to be in line with the statement of Wang (2015), which explains how the role of social services from the police.

Furthermore, Wang says that the form of social services from the police is a service which provides assistance and maintenance to the community in addition to the forms of the performance of the police in the form of obligations, enforcement of laws or regulations, control, and defense force in the society itself (Wang, 2015). The partnership is a solution in the troubleshooting for problems that arise in the community for police officers.

As described by Goldstein (1990) in a book written by Wang (Wang, 2015) with the title Empowerment on Chinese Police Force's Role in Social Services that community policing is useful to improve the service and performance of the police. (Wang, 2015).

Then with the explanation of Goldstein can be interpreted that community policing is a strategy of policing that is proactive, which offers solving problems of the society through cooperation in the form of a partnership between the police with the community. Same with the journal that written by O'Neill and McCarthy (2014) with the title (Re) negotiating police culture through partnership working: Trust, compromise, and the 'new' pragmatism that partnership can be used as a means to manage the problems that arise in the society. The partnership is a form of the solution in carrying the tasks and functions of police in society (O'Neill \& Daniel, 2014). 


\section{Conclusion}

Based on the results of the analysis, and comparing with the criteria set by the WHO, it is known that of the five parameters used by WHO in determining the standard of safety on the highway, only four rules have been applied in the regulation of the traffic in Indonesia. Of the four regulations that have been applied in Indonesia, there is one that applies but partially, i.e. rules related to the use of safety belts for passengers next to the driver, but there are no rules for a passenger behind the driver when it is in the middle and behind the driver itself.

It can be said that only about $70 \%$ of the rules used as a standard by WHO that already followed by regulations in Indonesia. Data taken from the report of the public Korlantas that is Police in Numbers 2013, shows that the factor of the driver has a very important role in causing of the accident, where the driver becomes the dominant factor in the occurrence of the accident, there are approximately $88 \%$ of accidents are caused by human factors, in which Disobedient Attitude (45,7\%) to driver behavior that mostly leading to accidents followed by Neglectfulness (32,2\%) and Violation of Speed (14,5\%).

To lower the level of risk of traffic accidents in Jakarta, things to do is to provide education to the community to understand the importance of traffic safety, and obey the rules on the road when driving. This has been done by the police by conducting educational activities to many parties that have the interest and use the highway. That approach is the community approach or called with the community policing (Community Policing).

Community Policing Approach is more advisable compared with the approach of Society Policing, because with the focus to the community that the message conveyed is easy to be accepted, because in one particular community there is pressure from other community members to adhere to the rules that already known. On the other hand, the community also expected the existence of common purpose or vision or cohesion among the members of the community. Other things that become advantage of Policing Community is the focus on smaller, more homogeneous so that it becomes easier in the educational process to be done. The implementation of community policing often faces problem in the financing, but the role of the community can be invited and to participate actively to play the roles and take some of the roles of the police as a reminder if there is a violation of the rules, maintain orders and regularity in the highway. So that the community members will feel that safety and security are shared responsibility, not just solely the responsibility of the police. 


\section{References}

Aeron-Thomas, A. (2003). Community Traffic Policing Scoping Study: Final Report. Berkshire: TRL Limited.

Alach, Z. J. (2010). Policing and Effects-Based Operations: Modelling Methamphetamine. Policing: An International Journal of Police Strategies $\mathcal{E}$ Management, Vo.33, No.3, 490-505.

Badh, V. K. (2014). It Is No Accident that is Called an Accident: Vehicular Negligence ( A Sosio-legal Study of Crime, Law, and Public Safety). United States: Proquest LLC.

Brantingham, P. J. (2010). Crime Prevention, Domains of. In B. S. Fisher, \& S. Lab, Encyclopedia of Victimology and Crime Prevention. London: Sage Publication.

Bronitt, S., \& Stenning, P. (2011). Understanding Discretion in Modern Policing.

Crime, Justice and Social Democracy: An International Conference.

Quensland: Griffith University.

Community Oriented Policing Service. (2014). Community Policing Defined. Washington: U.S. Department of Justice.

Croft, P. (2009). Guide to Traffic Management Part 1: Introduction to Traffic Management. Sydney: Austroads.

Eck, J. (1998). Preventing Crime at Places. In L. Sherman, D. Gottfredson, D. Mackenzie, P. Reuter, \& S. Bushway, What Works, What Doesn't, What's Promising. Washington: National Institute of Justice.

Ekblom, P. (2001). The Conjunction of Criminal Opportunity: A Framework for Crime Reduction Toolkits, Policing, and Reducing Crime Unit Research. London: Development and Statistic Directorate Home Office.

Goldstein, H. (1990). Problem-Oriented Policing. New York: McGraw Hill: McGraw Hill.

Gray II, B. (1989). History and Principles of Crime Prevention and Security. In L. J. Fennelly, Handbook of Lost Prevention and Crime Prevention 2nd Edition. Butterworth: Heinemann.

Haley, J. O. (2011). Restorative Justice: Introduction. Washington University Journal of Law \& Policy.

Hobbs, F. (1995). Perencanaan dan Teknik Lalu Lintas. Jogjakarta: Gadjah Mada University Press. 
Lab, S. P. (2010). crime Prevention: Approaches, Practices, and Evaluations, 7th Edition. New Providence: RoutledgeMatthew Bender \& Company, Inc.

Liederbach, J., Fritsch, E., Carter, D., \& Bannister, A. (2008). Exploring the limits of collaboration in community policing. Policing: An International Journal of Police Strategies \& Management, Vol.31 No.2, 271-291.

Liou, K. T., \& Savage, E. (1996). Citizen Perception of Community Policing Impact. Public Administration Quarterly, Vol.20, No.2 (Summer), 163-179.

Livingston, D. (1997). Police Discretion and the Quality of Life in Public Places: Courts, Communities, and the New Policing. Columbia Law Review, Vol. 97, 551-672.

Lowenstein, H. (1984). Evaluating Public Sector Employee Performance: Police Productivity As A Case Study. Urbana: University of Illinois.

Mannheim, H. (1965). Comparative Criminology (Vol. 1). London: Routledge \& Kegan Paul.

Marshall, T. E. (1999). Restorative Justice: An Overview. London: Home Office Research Development and Statistics Directorate.

Moore, M. H. (1992). Problem-Solving and Community Policing. Crime and Justice Vo. 1, Modern Policing, 99-158.

Moore, M. H., Trojanowicz, R. C., \& Kelling, G. L. (1988). Crime and Policing. National Institute of Justice.

Muhammad, F. (1998). Traffic Law Enforcement Decision Making by Indonesia National Police. United States: UMI Company.

O'Brien, M., \& Yar, M. (2008). Criminology: The Key Concepts. Routledge.

O'Neill, M., \& Daniel, M. (2014). negotiating police culture through partnership working: Trust, compromise, and the 'new' pragmatism. Criminology $\mathcal{E}$ Criminal Justice, 14(2), 143-159.

Ponsaers, P. (2001). Reading about community (oriented) policing and police models. Policing 24, 470.

Punch, M., Vijver, K., \& Olga, Z. (2002). Dutch "COP" Developing Communiy Policing in The Netherlands. Policing. An International Journal of Police Strategies \& Management, Vol.25, No.1, 60-79.

Ramdlon, N. (1983). Menggairahkan Kesadaran Hukum Masyarakat dan Disiplin Penegak Hukum dalam Lalu Lintas. Surabaya: Bina Ilmu. 
Satjpto, R. (2001). Community Policing di Indonesia. Seminar Polisi: Antara Harapan dan Kenyataan. Jakarta.

Schafer, J. A., Carter, D. L., Katz-Bannister, A. J., \& Wells, W. M. (2006).

Decision Making In Traffic Stop Encounters: A Multivariate Analysis Of Police Behavior. Police Quarterly, 184-209.

Schneider, S. (2015). Crime Prevention: Theory and Practice, 2nd Edition. Boca Raton: Taylor \& Francis Group, LLC.

Siegel, L. J. (2000). Criminology. Stamford: Wadsworth.

Smith, R. G., Wolanin, N., \& Worthington, G. (2003). e-Crime Solutions and Crime Displacement. Trends and Issues in Crime and Criminal Justice, 2-6.

Umbreit, M. S. (1989). Crime Victims Seeking Fairness, Not Revenge: Toward Restorative Justice. Fed. Probation 53.

Wang, X. (2015). Empowerment on the Chinese Police Force's Role in Social Services. New York: Springer. 


\section{JURNAL}

\section{CITA HUKUM INDONESIAN LAW JOURNAL}

\section{TECHNICAL GUIDANCE FOR AUTHORS OF CITA HUKUM JOURNAL}

1. Article must be original, not plagiarism, unpublished, and not under review for possible publication in other journals.

2. Article should be concept, research-based, and toughts;

3. Article should be written in English

4. Article must contain of Law Science

5. Writing Guidance as follows:

a. Title is written by Capital maximum 12 words in the center

b. Name of authors are written completely, no degree, institutional affiliation, address, and email.

c. Abstract is written in English maximum 250 words.

d. Systematycs of article:

1) Title

2) Name of authors (no title), name of affiliation, email

3) Abstract

4) Keywords, between 3-5 words

5) Introduction

6) Sub title (if need it)

7) Closing

8) Bibliography (The bibliography list contains all references in text originating from sources that are relevant and at least up to date (last 10 years).

e. Paper Sizes are $17,5 \times 24 \mathrm{~cm}$, up $2,5 \mathrm{~cm}$, down, $2,5 \mathrm{~cm}$, right $2,5 \mathrm{~cm}$, and left $2,5 \mathrm{~cm}$

f. Length of article is between $18-20$ pages with 1.0 line spacing, Palatyno Fond Style with 10 size.

g. Rule of citation. Direct citation if word is more than 4 lines separated from the text with 1.0 spacing with 9 font. However if citation less than 4 lines, it should be integrated in the text with double apostrof both in the first and in the end. Every citation is given number. Citation system is body note and use turabia system. Every article, book, and other source should be citated on the reference.

h. Citation for Quran and Hadist. For verse citation contains name of surah, number of surah and number of verse example: (Qs. Al Mumin [40]: 43). For Hadis citation, mention name of Perawi/Author, example (H. R al-Bukhari and Muslim) and printed hadist version. Hadist must be from standar hadist books (Kutub at-Tisah). 
i. Bodynote is written by Palatino Linotype style, size 10, for any sources as: (Yunus, 2014: 144).

j. Bibliography. Bibliography is written alphabeticaly, last author's name is in the first of name, example:

1) Book: Soekanto, S. Pokok-Pokok Sosiologi Hukum, Jakarta: Rajawali Press, 1986.

2) Translated Book. Example: Pound, R. Pengantar Filsafat Hukum: Book III, translated by Moh. Radjab, Jakarta: Bharata, 1963.

3) Journal, example: Rohim, N. "Kontroversi Pembentukan Perppu No. 1 Tahun 2013 tentang mahkamah konstitusi dalam ranah kegentingan yang memaksa", Jurnal Cita Hukum, Volume 2 Number 1 (2014).

4) Article as a part of book (antology). example: Juwana, H. "Penegakan Hukum dalam Kajian Law and Development: Problem dan Fundamen bagi Solusi Indonesia", in Muhammad Tahir Azhary, Beberapa Aspek Hukum Tata Negara, Hukum Pidana, dan Hukum Islam, Jakarta: Kencana Prenada Media Group, 2012.

5) Article from internet, example: Kharlie, Ahmad Tholabie, "Problem Yuridis RUU Syariah" in http://ahmadtholabi.com/2008/03/03problem-yuridis-ruu-syariah, downloaded on March 20, 2012.

6) Article from magazine, example: Susilaningtias, "Potret Hukum Adat pada Masa Kolonial," in Forum Keadilan, No. 17, August 20, 2016.

7) Article in Seminar, example: Asshidiqqie, Jimly, "Kedudukan Mahkamah Konstitusi dalam Struktur Ketatanegaraan Indonesia," paper presented on public lecture at faculty of law Universty Sebelas Maret, Surakarta on March 2, 2014.

k. Closing, article is closed by conclusion;

I. Short biography: author's biography contains full name, title, institution, education and other academic experts.

6. Every article that doesnt fufill all requirements to this guidance will give it back to the author for revision.

7. Article must be submitted to editors at least 3 months before publishing (April, August, and December) with uploading via OJS to http://journal.uinjkt.ac.id/index.php/citahukum or e-mail to jurnal.citahukum@uinjkt.ac.id.] 
in Collaboration with :

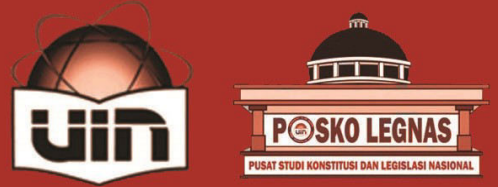

Indexed by :
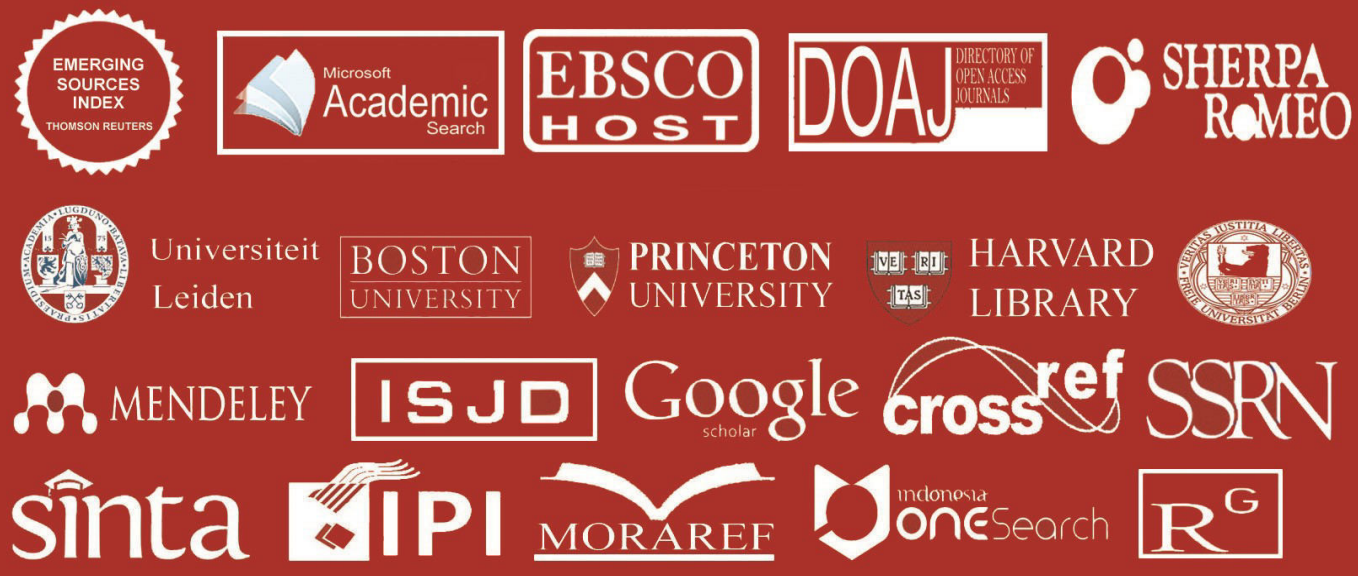

JURNAL CITA HUKUM is a peer-reviewed journal on Indonesian Law Studies published biannual (June \& December) by Faculty of Sharia and Law Universitas Islam Negeri Syarif Hidayatullah Jakarta in cooperation with Center for the Study of Constitution and National Legislation (POSKO-LEGNAS). JURNAL CITA HUKUM aims primarily to facilitate scholarly and professional discussions over current developments on legal issues in Indonesia as well as to publish innovative legal researches concerning Indonesian laws.
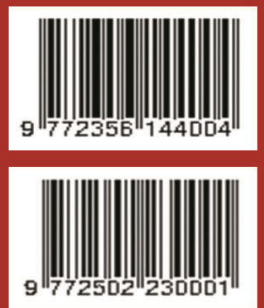